\title{
NATIONAL ACCOUNTS AT CONSTANT PRICES
}

\author{
BY J. B. BRODERICK \\ Central Statistics Office, Dublin
}

\begin{abstract}
This article discusses the problem of compiling a balanced set of national accounts at constant priccs. The mcthod adopted is based on earlier work on this subject by Burge and Geary. Commodity flows, which are uniquely deflatable, are expressed at constant prices and savings in constant prices is obtained by preserving a balanced set of cquations in real terms. The deflation of the external account is discussed.

A method is suggested for expressing the national income account in real terms and an "income gain" is deduced for each industrial sector which represents the difference between real income and real product in that sector. The sum of the income gains for the domestic sectors is zero.

The constituents of the income/expcnditure accounts of households, corporations and general government are expressed at constant prices by selecting suitable deflators in a consistent manner. The accounts in real terms are now unbalanced and are balanced again by inserting a balancing item which is shown to represent a gain to the sector arising from changes in the terms of trade between the sectors. This item is called an "expenditure gain." The sum of the expenditure gains for the institutional sectors is zero.

The system suggested can be extended to cover additional items in the accounts and thus a complete set of national accounts in real terms can be derived.
\end{abstract}

Although national accounts are compiled annually by nearly all countries and recommendations relating to their compilation are contained in the U.N. publication, "A System of National Accounts and Supporting Tables" (S.N.A.) which is now undergoing revision, and in the O.E.C.D. publication, "A Standardised System of National Accounts", the systems of national accounts in current use do not provide guidance for the compilation of accounts at constant prices. Yet for many purposes the compilation of the data in national accounts at constant prices in order to indicate volume changes from year to year is more interesting and more valuable for economic analysis than the data in current prices.

Most countries, however, do compile gross domestic product or gross national product at constant prices and show the constituents of these totals. The compilations are made on the basis that gross domestic product can be broken down into commodity flows which can be identified with quantities of goods or services to which prices can be given. The two methods of estimation are the production method, which consists in aggregating the contributions valued at constant prices of different industries to the gross domestic product, and the expenditure method which consists in aggregating the constituents of final expenditure valued at constant prices. While most countries compile GDP in volume terms by using one or both of these methods there are still a number of problems met in these compilations on which guidance would be valuable, particularly for the purpose of ensuring that international comparisons of data in this field have a certain validity. No doubt the new S.N.A. will give recommendations on these matters.

Most workers in the field of constant price estimates have confined their attention to deflating commodity flows only. Formidable difficulties are encountered in deflating items in the accounts which cannot be identified with commodity flows, 
e.g., savings and transfers. Stone has discussed the matter and has shown that it is impossible to obtain a unique set of deflated values of the non-commodity transactions such that the accounts still balance in real terms. ${ }^{1}$ Burge and Geary have produced a simplified balanced set of accounts in constant prices, involving national income, savings and the external account and have lucidly explained the difficulties, ${ }^{2}$ and Stuvel has also considered the deflation of non-commodity flows. ${ }^{3}$ The deflation of income and expenditure accounts proper, e.g. Income and Expenditure of Households, Income and Expenditure of Corporations, Income and Expenditure of General Government, does not appear to have been covered by any of these workers.

Although there is no unique solution to the problem, it does appear desirable to develop a balanced set of accounts at constant prices, even if it is one of a number of sets which could be obtained. Such a system of accounts, of course, would have to be of use in economic analysis for there is little point in producing the accounts merely as an arithmetical exercise. However, until some systems are produced and tried out, their usefulness cannot be tested. A set of accounts at constant prices could be of use in several ways. Accounts in current prices lose much of their value in comparisons over time when the rates of inflation vary between countries and between the different sectors in each country. An analysis of accounts at constant prices may throw new light on economic relationships. A further reason for developing these accounts is in connection with economic development programs. Most advanced countries now prepare these programs as a guide to planning. In order to assess, however, whether targets have been reached, it will be necessary to express national accounts at constant prices and to compare such items as national income, savings and transfers with the projected values which are made at base year prices. There are many reasons, therefore, why the matter is worthy of study at the present time.

\section{Product and Income Accounts}

The Burge/Geary method of deflation appears to offer a good base on which to build a fully articulated system of balanced accounts. The following equations relate to a simple balanced set of accounts in current prices. For simplicity, items such as transfers have been omitted.

$$
\begin{aligned}
& \text { (1) } C+V+E-I=P \\
& \text { (2) } P+Z=C+S \\
& \text { (3) } S=V+B \\
& \text { (4) } B=E-I+Z
\end{aligned}
$$

where $\mathrm{P}=$ Domestic product, $\mathrm{C}=$ Consumption, $\mathrm{V}=$ Capital formation, $\mathrm{E}=\mathrm{Ex}$ ports of goods and services, $I=$ Imports of goods and services, $Z=$ Net factor income from abroad, $\mathrm{S}=$ Savings, $\mathrm{B}=$ Net external investment.

The accounts have the same form whether gross $(\mathrm{P}=$ gross domestic product, $\mathrm{V}=$ gross capital formation, $\mathrm{S}=$ savings including provision for depreciation) or net, where the items exclude depreciation. The accounts also have the same form whether at factor cost or at market prices.

Items in these accounts which can be identified with flows of goods and services 
are uniquely deflatable. Thus C, V, E and I can be deflated in one way only. If primed letters denote constant price items, then real product can be taken as equal to the sum of the four items on the left hand side of equation (1) expressed in real terms. Thus

$$
\mathrm{P}^{\prime}=\mathrm{C}^{\prime}+\mathrm{V}^{\prime}+\mathrm{E}^{\prime}-\mathrm{I}^{\prime}
$$

The deflation of account (4) poses problems which are lucidly discussed by Burge and Geary in the case when $Z=0$. Assuming for the moment that $Z^{\prime}$ is the deflated value of $Z$, the difficulty arises from the fact that $E^{\prime}-I^{\prime}+Z^{\prime}$ and $E-I$ $+Z$ can differ in sign. If $B^{\prime}$ were equated to $E^{\prime}-I^{\prime}+Z^{\prime}$, then $B$ and $B^{\prime}$ could differ in sign and it would clearly not be meaningful for a surplus (deficit) on external account in current prices to become a deficit (surplus) in constant prices. As Burge and Geary point out, most researchers reject this and introduce what is called the "trading gain" which is the difference between $B$ ' (the deflated value of B) and $E^{\prime}-I^{\prime}+Z^{\prime}$. Unfortunately it has not been possible to reach agreement about the deflation of $\mathrm{B}$ and $\mathrm{Z}$. Among the suggestions that have been put forward for deflation of $B$ are (i) deflation by an import price index, (ii) deflation by an import price index when $\mathbf{B}$ is negative and by an export price index when $\mathbf{B}$ is positive, (iii) deflation by the implied price index for gross domestic product, (iv) deflation by a capital formation price index. There is similar disagreement about the deflation of $\mathrm{Z}$.

While there are arguments in favour of each of the possibilities, which differ according to the sign of the external balance and the sign of the net factor income flow, it seems appropriate to deflate $\mathrm{B}$ and $\mathrm{Z}$ by the implied price index for imports of goods and services in the case when $\mathrm{B}$ is negative and $\mathrm{Z}$ is a net inward flow, which is usually the case in Ireland. It is interesting to refer here to a study undertaken by Geary ${ }^{4}$ in which he showed that the differences in the results obtained by using different deflators for $B$ are negligible in practice. It would appear, therefore, that for all practical purposes, it does not matter much how B and $\mathrm{Z}$ are deflated. The selection of suitable deflators might be made, therefore, on the basis that (i) they are reasonable from a commonsense point of view, (ii) they will lead to a balanced set of accounts, (iii) they will meet the test of consistency between two countries. Deflation of $Z$ by the price index for imports of goods and services if $Z$ is a net inward flow, and by the price index for exports of goods and services if $Z$ is a net outward flow would seem to satisfy these criteria, since a net inward factor income flow can be regarded as being used to purchase imports of goods and services. Similarly, deflation of $E-I$ by the import price index if $E-I$ is negative and by the export price index if $\mathrm{E}-\mathrm{I}$ is positive follows the criteria laid down.

If $p_{1}$ and $p_{e}$ are the implied price indexes for imports and exports of goods and services, respectively, then if $\mathrm{Z}$ is a net inward flow and $\mathrm{E}-\mathrm{I}$ is negative,

$$
\begin{aligned}
B^{\prime}-\left(E^{\prime}-I^{\prime}+Z^{\prime}\right) & =\frac{E-I}{p_{1}}+\frac{Z}{p_{i}}-\frac{E}{p_{e}}+\frac{I}{p_{i}}-\frac{Z}{p_{i}} \\
& =E\left(\frac{1}{p_{i}}-\frac{1}{p_{e}}\right)
\end{aligned}
$$

while if $\mathrm{Z}$ is a net inward flow and $\mathrm{E}-\mathrm{I}$ is positive, 


$$
\begin{aligned}
B^{\prime}-\left(E^{\prime}-I^{\prime}+Z^{\prime}\right) & =\frac{E-I}{p_{e}}+\frac{Z}{p_{i}}-\frac{E}{p_{e}}+\frac{I}{p_{i}}-\frac{Z}{p_{i}} \\
& =I\left(\frac{1}{p_{i}}-\frac{1}{p_{e}}\right)
\end{aligned}
$$

The expression

$$
\mathrm{E}\left(\frac{1}{\mathrm{p}_{\mathrm{i}}}-\frac{1}{\mathrm{p}_{\mathrm{e}}}\right) \text { or } \mathrm{I}\left(\frac{1}{\mathrm{p}_{\mathrm{i}}}-\frac{1}{\mathrm{p}_{\mathrm{e}}}\right) \text { is }
$$

positive when $p_{e}>p_{1}$ and is, therefore, termed the trading gain. Denoting the trading gain by $\tau^{\prime}$ the equation (4) in real terms becomes

$$
\mathrm{B}^{\prime}-\tau^{\prime}=\mathrm{E}^{\prime}-\mathrm{I}^{\prime}+\mathrm{Z}^{\prime}
$$

In order to preserve the articulation of the system of equations, it is necessary to add $\tau^{\prime}$ to account (2) in real terms and this gives national income in real terms. The four accounts in real terms are, therefore,

$$
\begin{aligned}
& \mathrm{C}^{\prime}+\mathrm{V}^{\prime}+\mathrm{E}^{\prime}-\mathrm{I}^{\prime}=\mathrm{P}^{\prime} \\
& \mathrm{P}^{\prime}+\mathrm{Z}^{\prime}+\tau^{\prime}=\mathrm{C}^{\prime}+\mathrm{S}^{\prime} \\
& \mathrm{S}^{\prime}=\mathrm{V}^{\prime}+\mathrm{B}^{\prime} \\
& \mathrm{B}^{\prime}-\tau^{\prime}=\mathrm{E}^{\prime}-\mathrm{I}^{\prime}+\mathrm{Z}^{\prime} .
\end{aligned}
$$

These four equations reduce to three independent equations and, since $C^{\prime}, V^{\prime}$, $\mathrm{E}^{\prime}, \mathrm{I}^{\prime}, \mathrm{Z}^{\prime}$ and $\mathrm{B}^{\prime}$ are known, the remaining variables $\mathrm{P}^{\prime}, \mathrm{S}^{\prime}$ and $\tau^{\prime}$ can be found from the equations.

The following implied price indexes can then be derived:

$$
\begin{aligned}
& \mathrm{p}_{\mathbf{p}}=\frac{\mathrm{P}}{\mathrm{P}^{\prime}}=\text { implied price index for domestic product. } \\
& \mathrm{p}_{\mathbf{c}}=\frac{\mathrm{C}}{\mathrm{C}^{\prime}}=\text { implied price index for consumption. (This can, of course, be sep- }
\end{aligned}
$$
arated into two price indexes for consumers' expenditure and government consumption, respectively, e.g. $\mathrm{p}_{\mathrm{h}}$ and $\mathrm{p}_{\mathrm{g}}$ )

$$
\begin{aligned}
& \mathrm{p}_{\mathrm{v}}=\frac{\mathrm{V}}{\mathrm{V}^{\prime}}=\text { implied price index for capital formation. } \\
& \mathrm{p}_{\mathrm{s}}=\frac{\mathrm{S}}{\mathrm{S}^{\prime}}=\text { implied price index for savings. }
\end{aligned}
$$

The constant price series of accounts is based on the method suggested by Burge and Geary which uniquely determines savings in constant prices. There are, however, many other items in the national accounts which are not directly related to commodity flows, e.g. direct taxes, transfer payments, personal income, trading profits, etc. Can a meaningful deflation of such items be made so that the accounts at constant prices balance and will the accounts be useful for economic analysis? The other principal items which should be expressed at constant prices in order to 
develop a fully articulated system are the constituents of the national income account and the constituents of the income/expenditure accounts of institutional sectors.

\section{The National Income Account at Constant Prices}

This account shows the income arising in each sector of the economy which, in current prices, is equivalent to the product in each sector. The account may be net (i.e. excluding depreciation) or gross (i.e. including depreciation). It is clear that the equality between income and product in each sector does not necessarily hold at constant prices. For instance, as is well known, a situation can arise in which the volume of agricultural production increases compared with the base year but, with lower agricultural prices, the incomes received by the agricultural sector could be lower than in the base year. If the prices of the final goods and services on which agriculturists spend their income have not fallen compared with the base year, it is clear that they will be worse off and that they have, therefore, suffered a decline in real income. This decline, of course, will be offset by an increase in real income elsewhere in the economy. Such gains or losses in the different sectors arise from changes in the terms of trade of the sector when each sector is considered as trading with all other sectors. They are analogous to the external trading gain.

It is difficult to measure accurately the gains and losses of the individual sectors, as this would necessitate the use of double deflation and a detailed study of input/ output relationships between the sectors. However, it does appear that these gains and losses can be estimated in a simple way by expressing the national income account in constant prices and comparing it with the national product account, distinguishing individual sectors. To do this total domestic income in real terms is taken as equivalent to total domestic product since it does not appear possible to allocate the external trading gain to individual domestic sectors. This means that total domestic income is deflated by the implied price index of total domestic product. Now it is clear that if all relativities between prices in the base year were maintained in the future then the equivalence of product and income in each sector would be maintained in real terms and the real income (or product) in each sector would be obtained by dividing current values by the implied price index of domestic product. Real income in each sector can be defined, therefore, as the current value deflated by the implied price index for total domestic product, thereby using the same deflator for each sector. The difference between real income (defined in this way) and real product is the "income gain" which has occurred in the sector as a result of changing terms of trade compared with the base year. The sum of all the income gains is zero.

This method of obtaining real income is an approximation for the more accurate method by which each sector's income would be deflated by a price index for the final goods and services purchased by the sector. Since, however, the major part of each sector's income is spent on consumers' goods and services, there should be little difference between the theoretically correct price indexes for the different sectors. The approximation, therefore, should be quite good.

In each sector income can be conveniently divided between "remuneration of employees" and "operating surplus" which is equivalent to trading profit and income from rent. As many researchers have observed income flows such as remunera- 
tion of employees can be expressed in constant prices by deflating current values by an appropriate price index to measure in real terms that part of production which employees receive. It can, of course, be argued that not all income received is spent but, since the proportion of income saved is small, deflation of the total employee income by a suitable index of consumer prices should not introduce significant errors. For such deflation the implied price index for personal expenditure seems appropriate. Deflation of employee remuneration by an index of employee remuneration in order to derive the "productivity increment" can also be carried out but this aspect of deflation is not considered in this paper. Having thus expressed employee remuneration at constant prices operating surplus at constant prices in each sector is then obtained as a residual. An implied price index for the operating surplus in the domestic economy can be derived by dividing the constant value into the current value. Let $p_{y}$ be the index derived in this way for the non-agricultural sector.

To illustrate the kind of information which emerges from the procedure suggested the following tables show (a) net national product at constant prices, (b) net national income at constant prices, for Ireland in 1958, 1961, 1963 and 1965, distinguishing three industrial sectors.

Net National Product at Constant (1958) Prices- $£$ million

\begin{tabular}{lrrrr}
\hline \multicolumn{1}{c}{ Sector } & 1958 & 1961 & 1963 & 1965 \\
\hline Agriculture & 119.9 & 138.8 & 136.7 & 136 \\
Industry & 130.6 & 160.8 & 181.9 & 204 \\
Other domestic & 201.8 & 220.8 & 233.9 & 246 \\
Net factor income from abroad & 32.4 & 36.2 & 36.2 & 44 \\
Net national product & 484.7 & 556.6 & 588.7 & 630 \\
\hline
\end{tabular}

Net National Income at Constant (1958) Prices- $£$ million

\begin{tabular}{lcccc}
\hline \multicolumn{1}{c}{ Sector } & 1958 & 1961 & 1963 & 1965 \\
\hline Agriculture & 119.9 & 130.0 & 122.6 & 126 \\
Employee remuneration & 16.3 & 16.4 & 15.3 & 16 \\
Operating surplus & 103.6 & 113.6 & 107.3 & 110 \\
(Income gain) & $(-)$ & $(-8.8)$ & $(-14.1)$ & $(-10)$ \\
Industry & 130.6 & 158.4 & 177.5 & 187 \\
$\quad$ Employee remuneration & 99.2 & 124.3 & 144.2 & 159 \\
Operating surplus & 31.4 & 34.1 & 33.3 & 28 \\
(Income gain) & $(-)$ & $(-2.4)$ & $(-4.4)$ & $(-17)$ \\
Other domestic & 201.8 & 232.0 & 252.4 & 273 \\
Employee remuneration & 141.7 & 167.0 & 183.6 & 207 \\
Operating surplus & 60.1 & 65.0 & 68.8 & 66 \\
(Income gain) & $(-)$ & $(+11.2)$ & $(+18.5)$ & $(+27)$ \\
Net factor income from abroad & 32.4 & 36.2 & 36.2 & 44 \\
Trading gain & - & +1.6 & +5.6 & +16 \\
\hline Net national income & 484.7 & 558.2 & 594.3 & 646 \\
\hline
\end{tabular}


Net national income differs from net national product by the external trading gain which amounted to $£ 16$ million in 1965 . In both the sectors agriculture and industry, real income fell behind the value of real product and the income losses of these sectors were balanced by an income gain in the other domestic sector.

\section{Income and Expenditure Accounts at Constant Prices}

The problems encountered in attempting to express the constituents of income and expenditure accounts at constant prices do not appear to have received much attention. Three accounts with a limited number of constituents are considered in this section.

(i) Personal income and expenditure.

(ii) Income and expenditure of companies.

(iii) Income and expenditure of public authorities.

To deflate constituents in these accounts to constant prices the following principles are adopted.

(1) For non-commodity flows the price index used for deflation should be based on the price of goods and services for which the income is or could be exchanged.

(2) The same item should always be deflated by the same index, irrespective of which account it appears in. Consistency should also be preserved by deflating separately parts of items where these parts have already been deflated in other accounts.

(3) The accounts derived at constant prices should balance but this may be achieved by introducing new items analogous to the trading gain in the external account.

There is a close analogy between the deflation of an income/expenditure account and the deflation of the external transactions account. The difference between income and expenditure-saving or dissaving - can be compared with the difference between exports and imports of goods and services-the positive or negative external balance. Just as a term called the trading gain was introduced to balance the external account in real terms it is necessary to introduce a corresponding item to balance an income/expenditure account in real terms.

Let $\alpha=$ total income, $\beta=$ total expenditure and $S=$ savings in any account. Let us assume that the constituents of $\alpha$ and $\beta$ have been deflated and that $\alpha^{\prime}$ and $\beta^{\prime}$ are the deflated values of $\alpha$ and $\beta$ obtained by summing the constituent deflated values. In general $\alpha^{\prime}-\beta^{\prime}$ will not equal $S^{\prime}$, where $S^{\prime}=\frac{S}{p_{s}}$. The account can, however, be balanced by introducing a balancing item equal to

$$
\mathrm{S}^{\prime}-\left(\alpha^{\prime}-\beta^{\prime}\right)=\theta \quad(\text { say })
$$

Then

$$
\theta=\frac{\alpha-\beta}{\mathrm{p}_{\mathrm{s}}}-\frac{\alpha}{\mathrm{p}_{\alpha}}+\frac{\beta}{\mathrm{p}_{\beta}}=\alpha\left(\frac{1}{\mathrm{p}_{\mathrm{s}}}-\frac{1}{\mathrm{p}_{\alpha}}\right)-\beta\left(\frac{1}{\mathrm{p}_{\mathrm{s}}}-\frac{1}{\mathrm{p}_{\beta}}\right)
$$

where $\mathrm{p}_{\alpha}$ and $\mathrm{p}_{\beta}$ are the implied price indexes of $\alpha$ and $\beta$. This balancing item, which vanishes when $\mathrm{p}_{\alpha}=\mathrm{p}_{\beta}=\mathrm{p}_{\mathrm{s}}$ is analogous to the trading gain. 
Equation (9) can be written:

Real income + Balancing item $=$ Real expenditure + Real savings.

In form this is similar to the external account:

Real exports + Trading gain $=$ Real imports + Real external balance.

This indicates that the balancing item is a real gain because, to obtain a certain volume of real expenditure and real saving, real income and the balancing item are exchanged. Consider, for example, a simple account in which income $=$ expenditure, savings being zero. Should the prices of items of expenditure decline, then the same income would buy a larger volume of goods and services. Although income $=$ expenditure in current prices, a greater quantity of goods has been exchanged for the income and when income and expenditure are deflated real income will be lower than real expenditure. The item introduced on the income side to balance the account is, therefore, a measure of the gain that has occurred in the sector and it may be referred to as an "expenditure gain". This "expenditure gain" is a measure of the transfer of purchasing power to the sector as a result of relative price changes in the economy. It should, therefore, have an analytical usefulness although it must be pointed out that its level depends on the price indexes used to deflate the items on both sides of the income/expenditure account. It can be shown that the sum of the expenditure gains of the three institutional sectors, households, corporations, and government, is zero, provided the three principles adopted for deflation are maintained. (See Appendix.)

To express an income/expenditure account in constant prices, it is necessary, therefore, to deflate the constituents and introduce the "expenditure gain" to balance the account. Consider first the deflation of personal income which is derived from national income as follows:

$$
\begin{array}{ll} 
& \text { National income } \\
\text { less } & \text { Government trading and investment income } \\
\text { less } & \text { Undistributed profit of companies } \\
\text { plus } & \text { Transfer payments } \\
= & \text { Personal income. }
\end{array}
$$

It would not be correct to deflate these items as they stand since undistributed profit incorporates savings which is connected with the "expenditure gain" so that undistributed profit should be replaced by:

Trading profit plus non-trading income less distributed profit.

Then the income/expenditure account of households, etc., may be written as shown on the following page.

In this account national income (see equation (6)) and consumers' expenditure have already been expressed at constant prices. To deflate trading profit of companies $p_{y}$ (already derived) is used. The items non-trading income of companies, distributed profit, government trading and investment income, transfer payments and taxes on income must be divided up into flows to and from abroad (in which case $p_{i}$ must be used as a deflator following principle (2)) and flows between domestic sectors, where the choice of deflators is arbitrary. But since transfer payments are paid to the household sector and taxes on income are paid by the sector it seems 
Personal Income And Expenditure

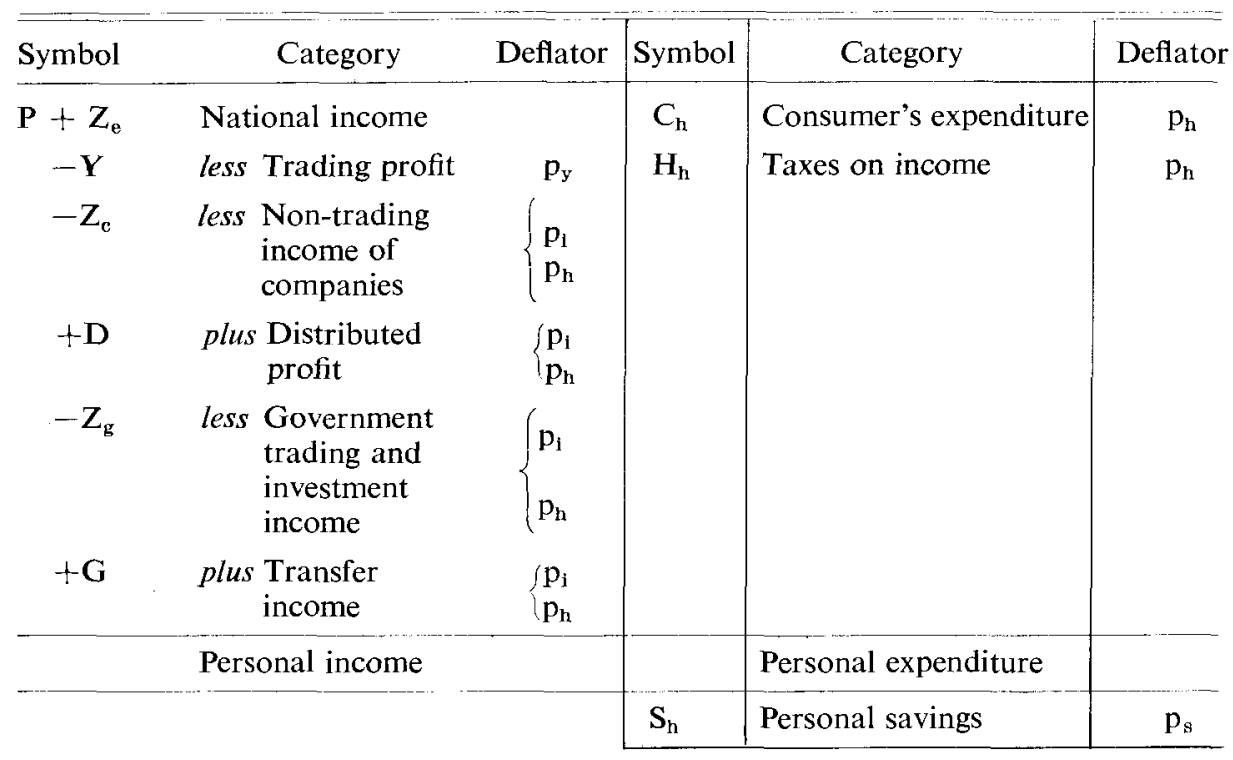

NoтE: Suffices are used to distinguish the sectors. Thus in relation to the symbols $\mathrm{Z}, \mathrm{C}$, $\mathrm{H}$, etc., the suffix e denotes the rest of the world, $\mathrm{g}$ denotes general government and $\mathrm{h}$ denotes households and private non-profit institutions. Similarly, $\mathrm{p}_{\mathrm{h}}$ denotes the implied price index for personal expenditure on consumers' goods and services, etc.

appropriate to use $p_{h}$ as a deflator for these items (principles (1) and (2)), apart from that part of transfer payments already in the external account which must have $p_{i}$ as deflator. The same reasoning applies to distributed profit since the greater part of this item is paid to households. Although the choice of deflators for the domestic parts of non-trading income of companies and government trading and investment income is not so clear-cut it seems reasonable to use $p_{h}$ for these constituents also since non-trading income of companies is made up partly of flows from households and partly of flows of national debt interest from government. Personal savings, of course, has already been expressed at constant prices (equations (5) to (8)).

The account for companies is as follows:

INCOME AND EXPENDITURE OF COMPANIES

\begin{tabular}{ccc|c|c|c}
\hline Symbol & Category & Deflator & Symbol & Category & Deflator \\
\hline $\mathrm{Y}$ & Trading profit & $\mathrm{p}_{\mathrm{y}}$ & $\mathrm{D}$ & Distributed profit & $\left\{\begin{array}{l}\mathrm{p}_{\mathrm{i}} \\
\mathrm{p}_{\mathrm{h}}\end{array}\right.$ \\
$\mathrm{Z}_{\mathbf{c}}$ & Non-trading income & $\left\{\begin{array}{l}\mathrm{p}_{\mathrm{i}} \\
\mathrm{p}_{\mathrm{h}}\end{array}\right.$ & $\mathrm{H}_{\mathrm{c}}$ & Taxes on income & $\mathrm{p}_{y}$ \\
\hline & Total income & & & Total expenditure & \\
\hline & & & $S_{\mathrm{c}}$ & Company savings & $\mathrm{p}_{\mathrm{s}}$ \\
\hline
\end{tabular}


The only item for which a deflator is not already available is taxes on income and, since the taxes on income are part of trading profits, it seems justifiable to use $p_{y}$ as a deflator for this item.

The account for public authorities (general government) is as follows:

InCOME AND EXPENDiture of Public Authorities

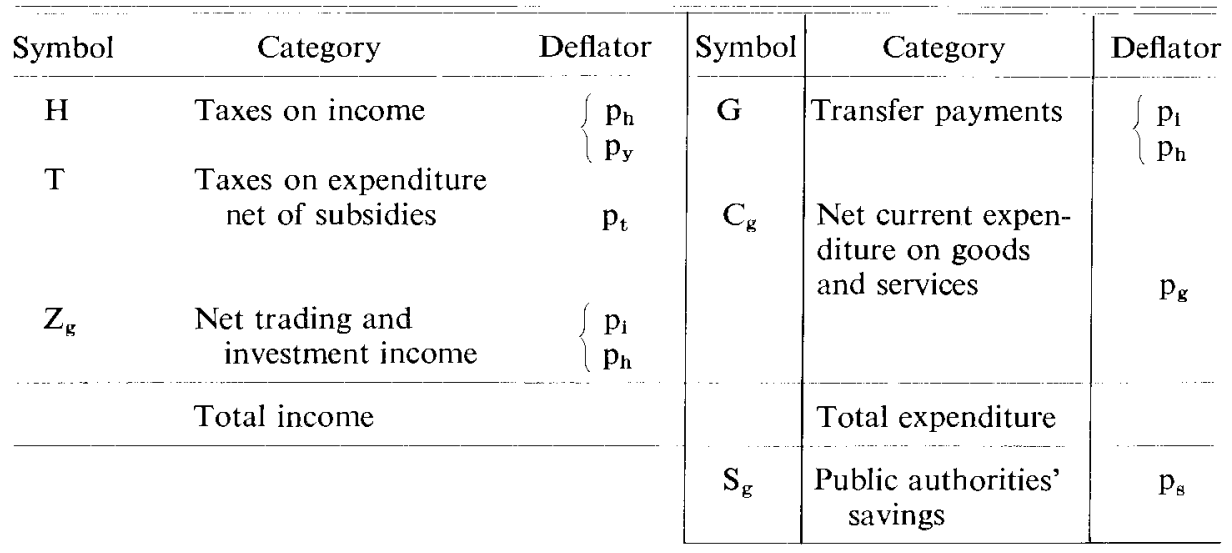

Taxes on expenditure and subsidies are deflated by the usual methods in deriving national product, as is net current expenditure on goods and services. The deflators for the other items follow from principle (2).

Having carried out the deflation procedures indicated, the three accounts will no longer be balanced in constant prices. The item introduced to balance each account is what has been referred to as the "expenditure gain". For each account

$$
\text { Real income }+ \text { Expenditure gain }=\text { Real expenditure }+ \text { Real savings }
$$

and the magnitude of the expenditure gain is a measure of the transfer of purchasing power to the sector as a result of relative price movements in the economy. The sum of the expenditure gains in the three institutional sectors is zero.

\section{Alternative Treatment of Savings}

In the treatment outlined above real savings has been obtained by solving equations (5) to (8) and the implied price index for savings has then been applied to the savings in each of the three institutional sectors to derive real savings in each sector. It might be questioned whether it would not be more logical to treat the savings of each sector separately. This, indeed, can be done without much modification to the system. Since savings is the balancing item in any account in current prices,

$$
\text { Income }=\text { Expenditure }+ \text { Savings }
$$

and it would be appropriate to regard savings as part of income and to deflate it by the implied price index for income. If this procedure is adopted $p_{s}=p_{a}$ in equation (9) and $\theta=-\beta\left(\frac{1}{\mathrm{p}_{a}}-\frac{1}{\mathrm{p}_{\beta}}\right)$. The interpretation of $\theta$ is still the same. However, a modification would be necessary to equations (5) to (8) since the value of $S^{\prime}$ is now 
determined and, in general, it is not equal to $\mathrm{V}^{\prime}+\mathrm{B}^{\prime}$. Therefore, in equation (6) and (7), $S^{\prime}$ would be replaced by $S^{\prime}+\tau^{\prime \prime}$, where $\tau^{\prime \prime}$ is an internal trading gain in the capital account due to relative price movements in the economy. In fact equation (7) would then be interpreted as

Real savings + Trading gain $=$ Real capital formation + Real external investment.

\section{Conclusion}

The system of accounts set out in this paper provides a complete balanced set of accounts at constant prices and although, for the purpose of exposition, certain items have been omitted from the accounts, it does appear possible to extend the system and to make provision for extra items. No doubt objections can be raised about the use of arbitrary deflators for non-commodity flows but these objections lose some of their force when, as has been shown by Geary and Pratschke in the case of the external account, the use of different deflators produces practically identical results. Therefore, while from the point of view of mathematical theory no unique set of constant price estimates for non-commodity flows can be obtained, as demonstrated by Stone, it does appear to be useful to compile national accounts at constant prices since the resulting figures obtained will probably be well within the limits of statistical errors of estimation, even though price indexes used for deflation are, in some cases, arbitrary. Furthermore, it seems to be quite appropriate to deflate many of the larger non-commodity flows by a price index for consumers' expenditure on goods and services and this narrows down the element of arbitrariness introduced in the accounts.

An economic meaning has been given to the items introduced to balance the accounts in constant prices and a study of these items in the accounts might yield valuable information. A matter of major importance is that the figures for "income gain" and "expenditure gain" are affected by the methods used to derive the real product in each sector. For instance it is well known that most countries base the real product in a large part of the services sector on the trend in numbers at work, thus assuming no productivity change. Since, however, incomes tend to rise in the services sector as fast as in other sectors, an "income gain" will tend to emerge in this sector at the expense of other ind ustrial sectors. In a similar way an "expenditure loss" will tend to occur in public authorities and there will be consequential "expenditure gains" in the other institutional sectors, since the major part of government current expenditure in real terms is considered to increase pro rata with the numbers at work while, on the other hand, a large part of real government income will tend to move in line with production of goods and services in the other sectors, which increases at a faster rate than the numbers at work in the public authorities sector. It seems to be a matter of urgency, therefore, to improve the methods used to estimate real output in the services sector because these figures are required both to compare this sector with other industrial sectors and to provide basic data for the meaningful extension of deflation into the area of non-commodity flows.

The problem of developing a complete set of national accounts at constant prices must be faced. Perhaps the most urgent reason for developing such a system is for the assessment of the degree of attainment of targets set out in economic 
development programs which are now being prepared in many countries for periods of ten to twenty years.

\section{REFERENCES}

(1) R. Stone-Quantity and Price Indexes of National Accounts, O.E.E.C., Paris, 1956.

(2) R. W. Burge and R. C. Geary-Balancing of a System of Accounts in Real Terms. Conference of the I.A.R.I.W., De Pietersberg, September, 1957.

(3) G. Stuvel-Asset Revaluation and Terms of Trade Effects in the Framework of the National Accounts. Economic Journal, June, 1959.

(4) R. C. Geary and J. L. Pratschke--Some Aspects of Price Inflation in Ireland. Economic and Social Research Institute, Dublin, 2.

\section{APPENDIX}

Let $\theta_{1}, \theta_{2}$ and $\theta_{3}$ be the expenditure gains of households, corporations and public authorities, respectively. Then, with the notation indicated in the tables, we have

$$
\begin{aligned}
& \theta_{1}=\mathrm{P}^{\prime}+\mathrm{Z}_{\mathrm{e}}{ }^{\prime}+\tau^{\prime}-\mathrm{Y}^{\prime}-\mathrm{Z}_{\mathrm{c}}{ }^{\prime}+\mathrm{D}^{\prime}-\mathrm{Z}_{\mathrm{g}}{ }^{\prime}+\mathrm{G}^{\prime}-\mathrm{C}_{\mathrm{h}}{ }^{\prime}-\mathrm{H}_{\mathrm{h}}{ }^{\prime}-\mathrm{S}_{\mathrm{h}}{ }^{\prime} \\
& \theta_{2}=\mathrm{Y}^{\prime}+\mathrm{Z}_{\mathrm{c}}{ }^{\prime}-\mathrm{D}^{\prime}-\mathrm{H}_{\mathrm{c}}{ }^{\prime}-\mathrm{S}_{\mathrm{c}}{ }^{\prime} \\
& \theta_{3}=\mathrm{H}^{\prime}+\mathrm{T}^{\prime}+\mathrm{Z}_{\mathrm{g}}{ }^{\prime}-\mathrm{G}^{\prime}-\mathrm{C}_{\mathrm{g}}{ }^{\prime}-\mathrm{S}_{\mathrm{g}}{ }^{\prime}
\end{aligned}
$$

and

$$
\begin{aligned}
\theta_{1}+ & \theta_{2}+\theta_{3}=\mathbf{P}^{\prime}+Z_{\mathrm{e}}{ }^{\prime}+\tau^{\prime}-\mathrm{C}_{\mathrm{h}}{ }^{\prime}-\mathrm{C}_{\mathrm{g}}{ }^{\prime}+\mathrm{T}^{\prime}-\left(\mathrm{S}_{\mathbf{h}}{ }^{\prime}+\mathbf{S}_{\mathrm{c}}{ }^{\prime}+\mathbf{S}_{\mathrm{g}}{ }^{\prime}\right) \\
& \text { since } \mathrm{H}^{\prime}=\mathrm{H}_{\mathbf{c}}{ }^{\prime}+\mathrm{H}_{\mathbf{h}}{ }^{\prime} \\
= & \mathrm{P}^{\prime}+\mathrm{Z}_{\mathrm{e}}{ }^{\prime}+\tau^{\prime}-\mathrm{C}_{\mathrm{h}}{ }^{\prime}-\mathrm{C}_{\mathrm{g}}{ }^{\prime}-\mathrm{S}^{\prime}+\mathrm{T}^{\prime} \\
= & \mathrm{P}^{\prime}+\mathrm{Z}_{\mathrm{e}}{ }^{\prime}+\tau^{\prime}-\mathrm{C}^{\prime}-\mathbf{S}^{\prime}+\mathrm{T}^{\prime} \\
= & 0
\end{aligned}
$$

since $\mathrm{P}^{\prime}+\mathrm{Z}_{\mathrm{e}}{ }^{\prime}+\tau^{\prime}$ has been taken at factor cost, $\mathrm{C}^{\prime}$ is at market prices and $\mathrm{T}^{\prime}$ is taxes on expenditure less subsidies.

Cet article discute le problème d'établir un ensemble cohérent de comptes nationaux en prix constants. La méthode adoptée est basée sur le travail antérieur de Burge et Geary sur ce sujet. Les flux externes de commodités peuvent être exprimés de manière unique en prix constants. L'épargne en prix constants s'obtient à l'aide d'un ensemble cohérent d'équations en termes réels. L'article discute aussi la déflation des comptes du secteur externe.

L'auteur suggère une méthode qui permittrait d'exprimer les comptes du revenu national en termes réels. Ainsi l'on calcule un "gain de revenu" ("income gain") pour chaque secteur industriel qui représenterait la difference entre le revenu réel et le produit réel de chaque secteur. La somme des "gains de revenu" pour les secteurs interieurs et égale à zéro.

La sélection systématique de déflateurs appropriés permit d'exprimer les éléments des comptes revenus-dépenses des ménages, des entreprises, et du gouvernement général en prix constants. Les comptes en termes réels qui en résultent ne balancent plus. On peut les faire balancer à nouveau en insérant un élément equilibrant. On demontre que cet élément représente un gain au profit du secteur dû aux changements dans les termes des échanges entre les secteurs. Cet élément est appelé "gain de dépense." La somme des gains de dépense pour les secteurs institutionnels est égale à zéro.

D'autres éléments des comptes peuvent être inclus dans le système. On peut ainsi établir un ensemble complet de comptes nationaux en termes réels. 